\title{
Spatial Analyses in the Research of Land Cover Changes (A Case Study)
}

\author{
Kinga Mazurek \\ Department of Physical Geography, Faculty of Earth Sciences, University of Silesia, 60 Bedzinska Str., \\ 41-200 Sosnowiec; mazurek.kingaa@gmail.com
}

Received: $27^{\text {th }}$ June, 2015

Accepted: $21^{\text {st }}$ September, 2015

\begin{abstract}
Increasing human activity significantly influences the geographic environment. The effects of excessive anthropogenic pressure are manifested by changes in land cover and in landscape structure, and land cover changes can particularly well observed in river valleys. In this study we aimed to determine the transformations of land use in $13.9 \mathrm{sq} \mathrm{km}$ of the Silesian Voivodeship in southern Poland, including parts of the city of Ruda Slaska and Mikolow County by analyzing changes in land cover that occurred from 1827-2012 and archival and contemporary topographic maps, and aerial photos were used as primary source materials. All materials were prepared with the use of Geographic Information Systems (GIS), using spatial analyses, such as kernel density and point density in order to define land cover structure changes.

Results show the development of residential areas and the fragmentation of large structures that have occurred over the time period.
\end{abstract}

Key words: spatial analysis, kernel density, point density, GIS, Klodnica river

\section{Introduction}

Increased human activity has had a significant impact on the state of the geographical environment. Visible transformations can be seen in the changes of natural landscapes, which are modified, reorganized, and or even permanently transmuted by anthropogenic factors. This is an inescapable aspect of urbanization and economic development. The constantly expanding and thickening settlement network in the Upper Silesian Metropolitan Union is already well developed. The Upper Silesian Metropolitan Union comprises 14 cities with a total area of 121,793 hectares, with a population density of 1,564 people/sq $\mathrm{km}$ (compared to the population density for the whole province of Silesia - 373 people/sq km, as of 2013, Local Government Statistical Handbook, 2014). Importantly, despite the developed settlement zones, transportation routes and land use for mining, manufacturing and services, the area is marked by a wide variation in terms of land use and land cover. Therefore, changes in land cover over time can be adopted as a subject of research. This study aimed to identify changes in land cover recorded on archival cartographic materials as well as their up-to-date current versions. The compositions depicting land cover for five time are presented, as well as the percentage determination of the changes. Transformation trends were established, i.e. which categories of land cover have largely transformed into other types of coverage. Simple spatial analyses were also applied. The primary function of these methodologies was to assess if the research area is part of a general trend that occurs between elements of land cover in the cities of the Katowice conurbation. In order to present the dynamics and directions of changes in the structure of land cover and, 
thus, for the presentation of changes in one of the components that make up the landscape, an analysis of changes in terms of chronostructure was adopted. By comparing archival topographic maps with modern cartographic materials, we were able to reconstruct former land use structure. Emphasis was placed on the proper selection of source materials, and their accurate development and interpretation. The time-range was established at 188 years, based on available maps. This allowed for an analysis in a complex temporal framework (Mazurek 2014).

\section{Study area}

The selected study area is located in the Upper Silesian Coal Basin, therefore the research proving ground is located in significantly transformed landscape. The area is located in southern Poland, in the central part of the Katowice conurbation, within the administrative borders of the city of Ruda Slaska and the County of Mikolow (Fig. 1), and drains into the Klodnica river (a tributary of the Oder). The study area was calibrated to the Polish hydro-graphic map 1:50,000, following the course of the watershed (Absalon et al., 2001). The hydrographic network in the study area consists of small streams and channels draining the area directly into the Klodnica. The area covers $13.9 \mathrm{sq} \mathrm{km}$. The physical and geographic regionalization, by Kondracki (2002), indicates that the Klodnica river catchment area belongs to the macroregion of the Silesian Highlands (341.1) and the meso-region of the Katowice Upland (341.13).

The geology here comprises UpperCarboniferous sandstone and coal-bearing shale covered with Tertiary clay, sandstone and gypsum, as well as Quaternary sediments.

The relief is predominantly of a horst and graben structure - with plateaus, and bottoms of valleys and basins. The original, natural relief has been modified as a result of mining activities and urbanization (Pełka-Gościniak \& Szczypek 2008).

\section{Materials and Methods}

Due to the location of research in the east of the historically significant Upper Silesia, it belongs to one of the most extensively mapped areas in Poland. Historically, the area has attracted the attention of regional as well as national authorities. Therefore, the studied area is rich in cartographic documentation. Five studies have been selected of all available materials, serving as base materials for the analysis:

1. Topographic map of Poland 1:10,000, 1994;

2. Urmesstischblätter $1: 25,000,1827$;

3. Messtischblätter 1:25,000, 1883;

4. Messtischblätter 1:25,000, 1942;

5. Orthophotomaps, 2012.

Three maps were Prussian and German cartographic materials. The oldest information comes from the Urmesstischblätter map documented at a scale of 1:25,000 based on triangulation measurements. The "Urmesstischblätter" maps were made in accordance with the guidelines specified by General Carl Friedrich Freiherr von Müffling, who was, at the time, chief of the Armed Forces. The measurements and mapping in Upper Silesia were made in the years 18241828 (Konias 2010). The sheets showing the catchment of the Klodnica, represent the field plan as of 1824, however, they were issued in 1827. The materials belong to the Collections of the National Mapping Division of the Library of Berlin - Prussian Cultural Heritage (Preussischer Kulturbesitz, http:// www.preussischer-kulturbesitz.de/). From 1858 to 1888 , measurements for new topographical images were taken. 


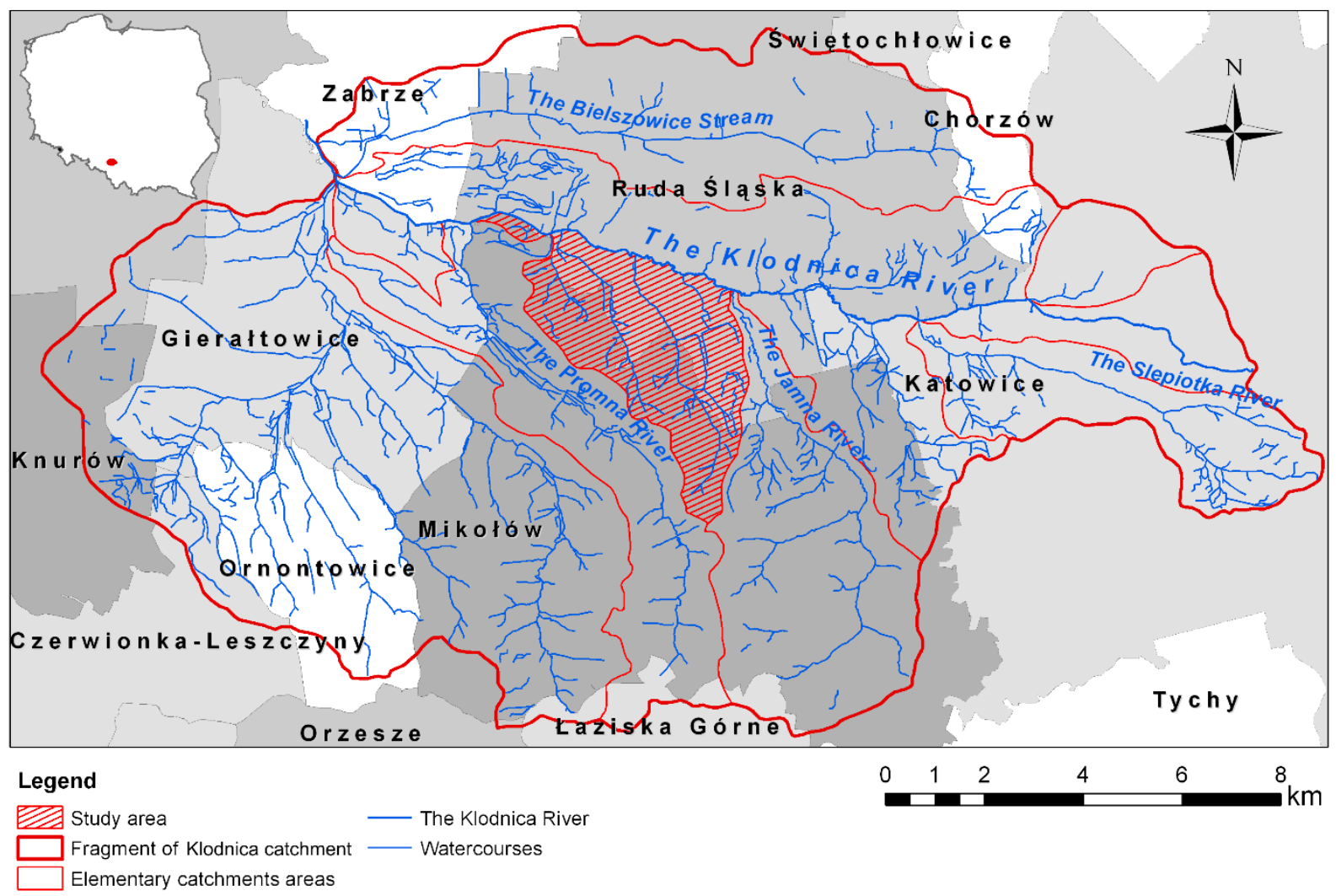

Fig.1. Location of the study area

The "Messtischblätter", map at a scale of $1: 25,000$, used table mapping with topographic steering. This map was based on newer, thickened triangulation networks and leveling (Jankowski 1961, Krynski 1970, Szaflarski 1965). The sheet consulted during this study was dated 1881. The subsequent edition of the "Messtischblätter" was systematically updated and issued until 1944. This topographic representation benefited from advanced photogrammetry, updating and field inventory (Krüger \& Schnadt 2000). The analyzed sheet dates from between 1940 and 1943. The "Messtischblätter" maps are also held by the State Library of Berlin - Prussian Cultural Heritage (Preussischer Kulturbesitz, http://www.preussischer-kulturbesitz.de/). The field plan of the 1990s was taken from the Polish topographical map at a scale of $1: 10,000$. The sheets issued by the Surveyor General were published between 1993 and 1994. The content of the maps is very general and the number of applied symbols is limited. The newest materials consist of orthophotomaps presenting the field plan as of 2012.

The map material has been calibrated and transformed into a UTM System of common coordinates (WGS 1984 Transverse Mercator). In the case of the nineteenth century materials, it was necessary to manually assign control points for proper calibration. Characteristic intersections of transportation routes, religious buildings and corners of map sheets served as points of convergence (Mazurek 2015b, Szymura et al., 2010). The created polygonal and linear layers, calibrated to the UTM System, correspond to individual elements of land cover. Categories of designated facilities were adapted to the content of the maps and properly aligned. Generalization of content allowed for the 9 polygon categories to be assigned: buildings, compact development, scattered developments, technical and 
industrial facilities, forest communities, areas with structured vegetation, grasslands, areas used for agriculture and wasteland, wetlands and marshy lands, and water-bodies. The transportation network was represented by the use of a poly-line (main roads, secondary roads, other routes, railroads, transmission lines) as were hydro-graphic networks (rivers, streams, drainage channels). Religious buildings were marked with points. Individual surface and linear structures were marked manually. Based on the developed components, the state of the geographical environment over time is presented as maps, with each category represented as an individual color (Fig. 2). The vector layer typology was verified in order to exclude the possibility of making mistakes while marking buildings. In addition, the tools used in the study included kernel density, point density and buffer. Kernel density (Spatial Analyst) in ArcGIS 10.2 was used to determine the density of the road network - road mileage per unit of land [sq $\mathrm{km}$ ] and was used for both main roads and secondary. The cell size was set at 1 . For all graphics, a uniform color scale was applied. Point density was used to determine the density of point objects per unit of land [sq $\mathrm{km}]$. Centroids were set for all buildings, which accounts for the input data.

\section{Results}

The contemporary land cover structure is clearly different from the one that existed in the early nineteenth century. Substantial changes in areas occupied by grasslands, areas used for agriculture and wasteland as well as wetlands and marshy lands, were observed with the simultaneous increase of built-up areas. Detailed information on the changes in land cover is presented in Table 1 . The table does not include values of less than $0.01 \mathrm{sq}$ $\mathrm{km}$.

In the area of research, the growing urbanization is noticeable, which manifests itself as expansion and densification of residential areas and associated infrastructure. Built-up areas increased from $0.04 \mathrm{sq} \mathrm{km}$ to $0.40 \mathrm{sq} \mathrm{km}$ (from $0.29 \%$ to $2.88 \%$ ). Residential buildings are closer together, forming a compact, rather than a scattered development. The buildings were initially grouped in three villages and dispersed hamlets (a total of 133 buildings). The settlement network developed as four housing estates and numerous scattered buildings (a total of 1,736 buildings). The area occupied by technical and industrial buildings increased by $0.29 \%$. Development in the transportation network and the overall mileage increased along with the percentage of paved roads. In addition, a railway junction between industrial plants was created and transmission lines were opened. In the case of roads, one should bear in mind the divergence in classification of roads by the authors of cartographic materials. The mileage of roads on the old maps was most probably determined by subjective evaluation and different typologies. Analyses here referred to the location and length of main and secondary roads. The rating of roads is based on their primary parameters (Table 2 ).

Railway lines in the study area were recorded on material from 1994 to 2012. The railway line was closely associated with industry - it only connected the coal mine with the power plant.

Areas occupied by ponds, wetlands and marshy lands decreased. The nine water-bodies present in 1827 occupied $1.73 \%$ (0.24 sq km) of the area. In 2012, despite the increase in the number of hydrographic objects, the total area amounted to $1.15 \%(0.16 \mathrm{sq} \mathrm{km})$. A significant increase in the area occupied by water-bodies in 1994 is noticeable. This was caused by the construction and operation of large septic tanks for wet waste from the "Halemba" power plant, located within the study area. The septic tanks were drained and liquidated from 2010 to 2012. 


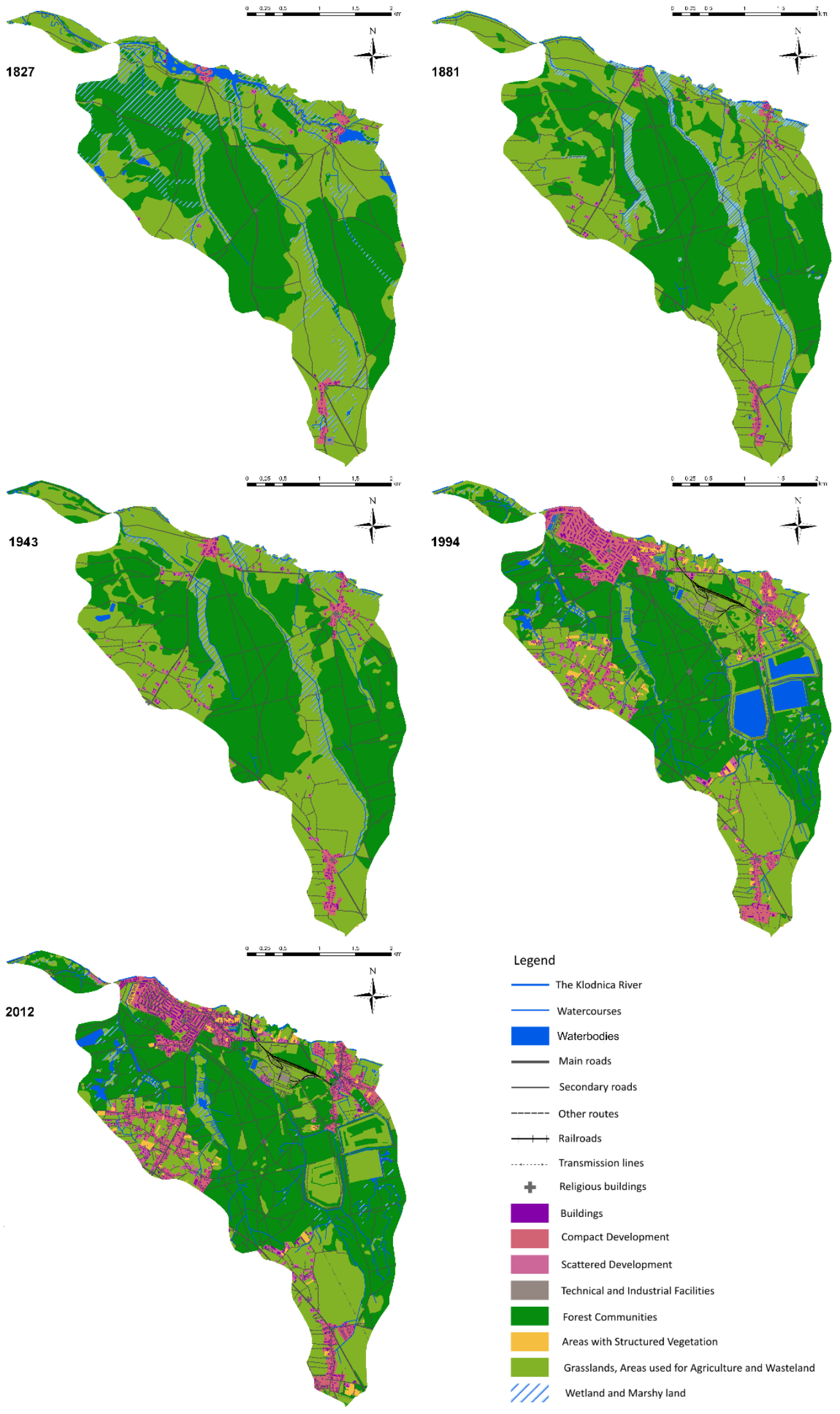

Fig.2. The structure of land use in the study area 
Tab.1. Quantity Data of the Land Use Categories

\begin{tabular}{|c|c|c|c|c|c|c|c|c|c|c|}
\hline & \multicolumn{2}{|c|}{1827} & \multicolumn{2}{|c|}{1881} & \multicolumn{2}{|c|}{1943} & \multicolumn{2}{|c|}{1994} & \multicolumn{2}{|c|}{2012} \\
\hline Categories & {$[\mathrm{sq} \mathrm{km}]$} & $\%$ & {$[\mathrm{sq} \mathrm{km]}$} & $\%$ & {$[\mathrm{sq} \mathrm{km}]$} & $\%$ & {$[\mathrm{sq} \mathrm{km}]$} & $\%$ & [sq km] & $\%$ \\
\hline Buildings & 0.04 & 0.29 & 0.05 & 0.36 & 0.10 & 0.72 & 0.33 & 2.37 & 0.40 & 2.88 \\
\hline Compact Development & 0.17 & 1.22 & 0.18 & 1.29 & 0.30 & 2.16 & 0.95 & 6.83 & 1.30 & 9.35 \\
\hline Scattered Development & 0.03 & 0.22 & 0.07 & 0.50 & 0.13 & 0.94 & 0.22 & 1.58 & 0.24 & 1.73 \\
\hline Technical and Industrial Facilities & 0.01 & 0.07 & No data & No data & No data & No data & 0.05 & 0.36 & 0.05 & 0.36 \\
\hline Forest Communities & 6.63 & 47.70 & 6.13 & 44.11 & 6.82 & 49.06 & 6.12 & 44.04 & 7.14 & 51.37 \\
\hline Areas with Structured Vegetation & No data & No data & No data & No data & No data & No data & 0.23 & 1.65 & 0.21 & 1.51 \\
\hline Grasslands, Areas used for Agriculture and Wasteland & 6.78 & 48.77 & 7.45 & 53.60 & 6.52 & 46.90 & 5.38 & 38.71 & 4.40 & 31.65 \\
\hline Wetland and Marshy land* & 2.77 & 19.93 & 1.08 & 7.77 & 0.90 & 6.47 & 0.25 & 1.80 & 0.38 & 2.73 \\
\hline Waterbodies & 0.24 & 1.73 & 0.02 & 0.14 & 0.03 & 0.22 & 0.62 & 4.46 & 0.16 & 1.15 \\
\hline
\end{tabular}

* Wetlands and marshy lands are not included in total percentage of the area because they were located in different types of land cover, mostly in meadows.

Tab.2. The division of transportation routes (primary, secondary and others)

\begin{tabular}{|c|c|c|c|c|c|}
\hline Categories & 1827 & 1881 & 1943 & 1994 & 2012 \\
\hline Primary routes & $\begin{array}{l}\text { Stone roads, ordinary } \\
\text { roads }\end{array}$ & $\begin{array}{c}\text { Roads located in Reich, } \\
\text { permanent roads (5,5m wide, } \\
\text { adjusted to trucks all seasons), } \\
\text { less permanent roads ( } 4 \mathrm{~m} \text { wide, } \\
\text { conditionally adjusted to } \\
\text { trucks), maintained roads, } \\
\text { adjusted to trucks at all weather } \\
\text { conditions }\end{array}$ & $\begin{array}{l}\text { Roads located in Reich, } \\
\text { permanent roads ( } 5,5 \mathrm{~m} \text { wide, } \\
\text { adjusted to trucks all seasons), } \\
\text { less permanent roads ( } 4 \mathrm{~m} \text { wide, } \\
\text { conditionally adjusted to trucks), } \\
\text { maintained roads, adjusted to } \\
\text { trucks at all weather conditions }\end{array}$ & $\begin{array}{l}\text { Highways, paved } \\
\text { roads, width: } 3-7 \mathrm{~m} \text {, } \\
\text { more than } 7 \mathrm{~m}\end{array}$ & $\begin{array}{c}\text { Highways, paved } \\
\text { roads with hardened } \\
\text { surface, width: } 3-7 \mathrm{~m} \text {, } \\
\text { more than } 7 \mathrm{~m}\end{array}$ \\
\hline Secondary routes & Roads, local roads & Maintained roads & Maintained roads & Paved roads & Paved roads \\
\hline Other routes & $\begin{array}{l}\text { Simple field roads, } \\
\text { paths }\end{array}$ & Field roads, forest roads, paths & Field roads, forest roads, paths & $\begin{array}{l}\text { Unpaved country } \\
\text { roads, unpaved forest } \\
\text { and field roads, paths }\end{array}$ & $\begin{array}{l}\text { Unpaved country } \\
\text { roads, unpaved forest } \\
\text { and field roads, paths }\end{array}$ \\
\hline
\end{tabular}


Watercourses were also modified - their total length increased from $22.20 \mathrm{~km}$ to $44.36 \mathrm{~km}$, which is associated with the ongoing drainage processes of the mining area. An increase was also recorded in the area occupied by forest communities (from $6.63 \mathrm{sq} \mathrm{km}$ to $7.16 \mathrm{sq} \mathrm{km}$ ). As shown by the data presented in the table, the area occupied by forests underwent noticeable fluctuations. Major changes relate to the grasslands; the land used for agriculture and wasteland decreased - from $6.81 \mathrm{sq} \mathrm{km}$ to $4.40 \mathrm{sq} \mathrm{km}$ (from $48.99 \%$ to $31.65 \%$ ). In addition, areas with structured vegetation have expanded.

The main directions of changes in the categories of land cover have been established. It was found that:

- an increase in the area occupied by the buildings took place at the expense of grasslands, land used for agriculture and wasteland, wetlands and marshy lands as well as forest communities.

- an increase in the area occupied by technical and industrial facilities took place at the expense of grasslands, agricultural land used and wasteland, forest communities as well as wetlands and marshy lands.

- an increase in the area occupied by forest communities took place at the expense of grasslands, land used for agriculture and wasteland, wetlands and marshy lands as well as water bodies.

In contrast, the wetlands and marshy lands have lost most of their surface to the benefit of forest communities, grasslands, agricultural land, wasteland and built-up areas.

Primarily attention was focused on two categories of land cover - buildings and transportation routes (Fig. 3).

Changes are visible in the location of areas with the highest density. The maximum calculated density varies from 6.77 in 1827 (with a standard deviation of 1.475), to 10.45 in 1881 , to 17.19 in 1943 , to 18.90 in 1994 , and reaching a value of 18.85 in 2012 (with a standard deviation of 3.0096). These changes correspond to changes in the density of buildings.

With the help of buffers, areas located within $50 \mathrm{~m}, 100 \mathrm{~m}$ and $250 \mathrm{~m}$ around the main roads were established, and the percentage participation of buildings located in different areas was determined along with its changes over time. Detailed data is contained in Table 3.

Tab.3. Percentage of buildings in the buffer zones of primary transportation routes.

\begin{tabular}{ccccc}
\hline Years & \multicolumn{5}{c}{ Buffer zones of the main roads } \\
& up to 50 & $51-100$ & $101-250$ & $>250$ \\
& $\mathrm{~m}$ & $\mathrm{~m}$ & $\mathrm{~m}$ & $\mathrm{~m}$ \\
\hline 1827 & $39.1 \%$ & $12.8 \%$ & $21.1 \%$ & $27.1 \%$ \\
1881 & $19.2 \%$ & $28.8 \%$ & $44.5 \%$ & $7.4 \%$ \\
1943 & $29.4 \%$ & $23.3 \%$ & $33.0 \%$ & $14.4 \%$ \\
1994 & $19.7 \%$ & $17.6 \%$ & $32.2 \%$ & $30.5 \%$ \\
2012 & $16.7 \%$ & $16.6 \%$ & $28.2 \%$ & $38.4 \%$ \\
\hline
\end{tabular}

A trend of representing a move away from main roads is apparent. The percentage of buildings located farthest from roads of the "main" class is increasing, and is associated with a decision to construct residential houses at a distance from major roads, as well as the fact that the immediate surroundings of these roads have already been developed.

A point density tool was activated several times. Cell size was established as 1 and automatic ranges as a color scale. Maximum density values were established, as were the formation and direction of "hot spots" forming regions with the highest density of the phenomenon (Fig. 4). Maximum values have changed over time as follows: 1827 - 562.79, 1881 - 562.79, 1943 - 613.13, 1994 - 1354.21 and 2012 - 1 313.86. The formation and development of areas with a high density of development is apparent. The highest values are recorded in two locations in the north of the study area, but high values are also visible in southern and western parts. 

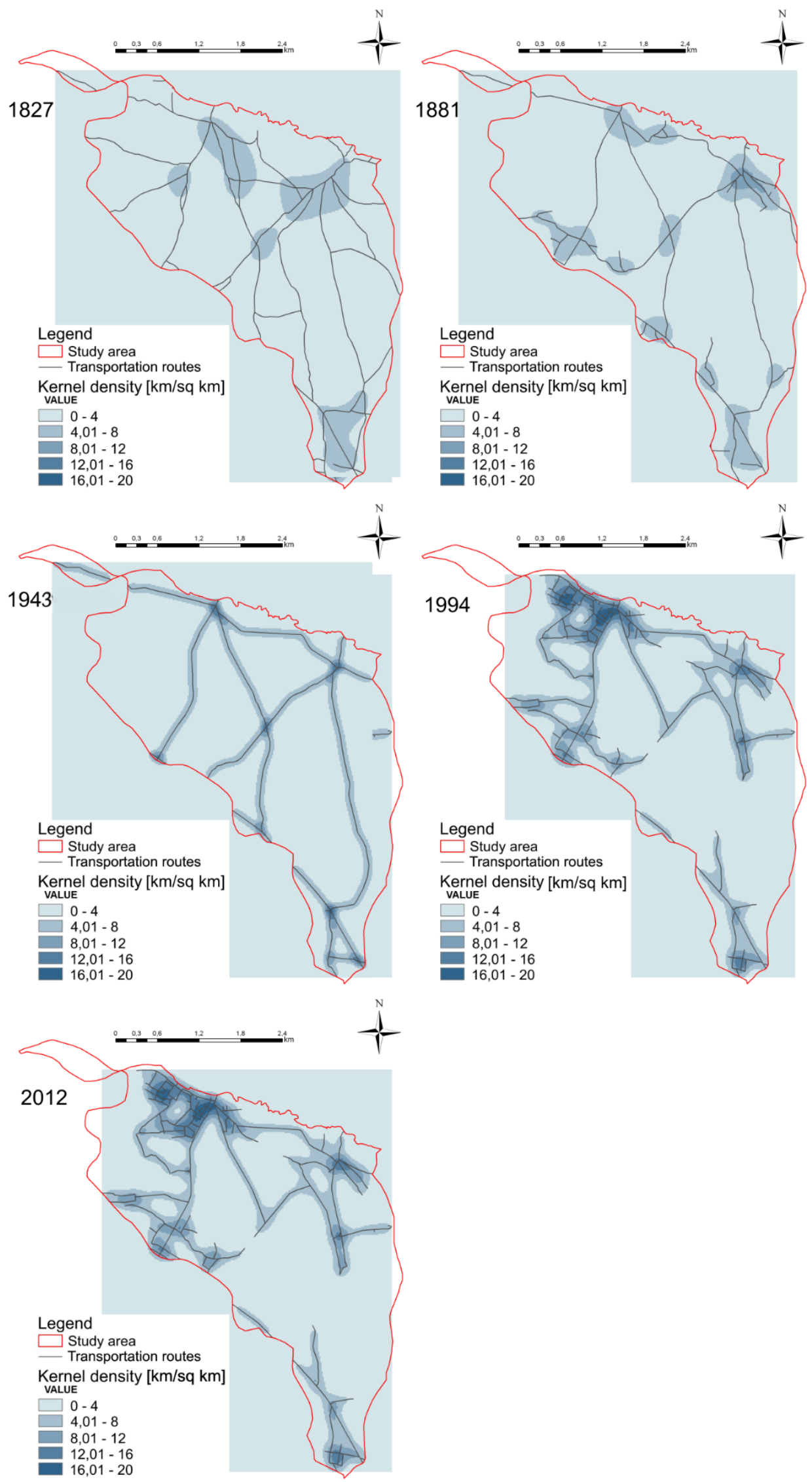

Fig.3. Kernel density of transportation routes (primary and secondary) 


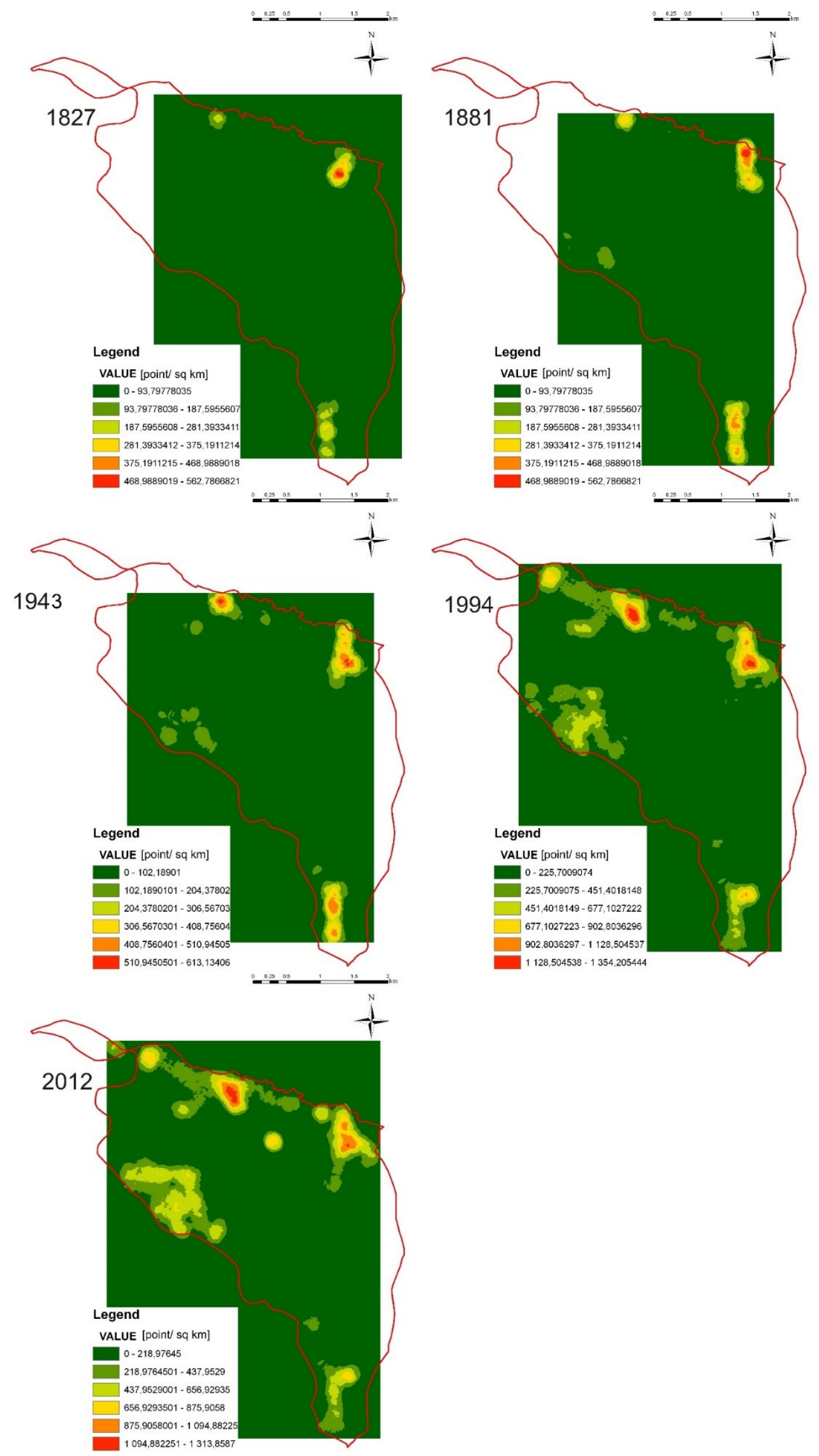

Fig.4. Point Density of buildings on square kilometer 


\section{Discussion}

The issue of changes in the structure of land use is a frequently discussed subject of research, both domestically and internationally (Drzewiecki 2008, Lambin 2001, Turner et al., 1996, Vogelmann et al, 2001, Xiubin 1996,). In Poland, the issue has been analyzed both at a national level (Ciołkosz \& Poławski 2005) as well as at a regional one (Kaim 2009). In the Upper Silesian Metropolitan Union, similar observations have been made by Czaja (1995), Czaja \& Rzętała (1999), and Dulias (2010). International programs and projects such as: the USGS Land Cover Institute (LCI), Corine Land Cover or the NASA Land-Cover and Land-Use Change (LCLUC) Program, designed to collect, process, analyze and share data on changes in land cover and land use are widely known. What is important, it is crucial to systematize concepts and classifications of types of land cover (Anderson et al., 1976, Foody 2002) and there are various methodological approaches applicable (Townshend et al., 1991; Yuan 2008).

Modifications of land cover or land use of this kind are most often presented in the context of intra-regional trends. In the cities of the Katowice conurbation, an additional aspect is the enhanced anthropogenic factor. Changes in land use in mining and post-mining areas have been the focus of many researchers (Dulias 2013). In addition, reclamation and remediation activities play an important part here since they contribute to restore the relatively "natural" land cover. In turn, the additional investment in the areas and their further reconstruction may contribute to some improvement in transport accessibility and investment attractiveness. Emphasis is placed on creating good infrastructural connections between urban centers and land development, taking into account maximum economic benefits. It is appropriate, however, to observe the principles of sustainable development that take into account the potential of individual elements of the geographical environment. In the research of land use changes and modifications to the local landscape, the assumptions contained in the Landscape Act should be considered and confronted with assumptions made in the local spatial development plans in order to have an outlook on any future projects.

The terms in the field of land use change analysis are still drawing attention due to multiple methods of interpretation, time frames and the study area itself. This provides many benefits such as research tools testing and discovering the ways of understanding.

\section{Summary}

This study presents the application of simple spatial analyses to research on land cover changes or transformations of landscape structure. These results made it possible to quantify the relationships and trends in land cover in the area of research. According to the initial assumptions, modifications of land cover structure within the research unit are undergoing continuous evolution, referring to a general direction of changes in the use of land. The changes taking place in the cities of mining origin, belonging to the Katowice conurbation, are visibly reflected, as are those taking place across the country. It can therefore be assumed that changes in the structure of land use corresponds with typical environmental impacts associated with the development of human settlements. The nineteenth century was a period when large areas were characterized by a single type of land use. Later, numerous smaller patches of land cover evolved, which split large homogeneous areas. In effect, a distinctive cultural landscape was formed.

A comparative analysis, carried out using cartographic material, allows for an assessment of landscape component changes in the area, or changes within one category of land cover. The summary of the percentage values of land 
cover outlines the direction and significance of changes in the landscape structure. In the period covered by the study, basic agricultural activities of the population were abandoned and transformed into intensive development of mining and heavy industry, which was followed by a partial divergence from industrial activities.

The development of source materials is of extreme importance, that is, the selection of the most appropriate cartographic materials with reliable content and the best quality of presentation, including the unification and definition of categories listed in the legend. Properly processed data will allow for the testing of multiple GIS (Geographic Information System) tools, including spatial analyses, as well as relevant parameters and configurations. This enables the selection and application of tools and procedures that will present the changes in the surrounding world in the most interesting and precise manner.

\section{References}

Absalon D., Jankowski A., Leśniok M. (2001) Hydrographic map of Poland 1:50 000, Sheets: M-34-62-B M-34-63-A, Surveyor General of Poland. Warsaw

Anderson J. R., Hardy E. E., Roach J. T., Witmer R. E. (1976) A Land Use And Land Cover Classification System For Use With Remote Sensor Data. Geological Survey Professional Paper, 964. Digital version 2001.

Ciołkosz A., Poławski Z. F. (2005) Land use changes in Poland in the second half of 20th century based on the analysis of land use maps. Polskie Towarzystwo Informacji Przestrzennej. Roczniki Geomatyki, 3, 2: 17-26. (In Polish: Zmiany użytkowania ziemii w Polsce w II połowie XX w. na podstawie analizy danych kartograficznych)

Czaja S. (1995) Changes in land use and the surface hydrographic network in the city of
Katowice in the period 1801-1985. Geographia Studia et dissertationes. Wyd. UŚ, Katowice, 19. (In Polish: Zmiany użytkowania ziemi i powierzchniowej sieci hydrograficznej na obszarze miasta Katowice w latach 1801-1985)

Czaja S., Rzętała M. (1999) Changes in land use and the surface hydrographic network in the city of Chorzów from the late eighteenth century to the present day. In: Kapała Z. (ed) Zeszyty Chorzowskie, 3. Chorzów. (In Polish: Zmiany użytkowania ziemi i powierzchniowej sieci hydrograficznej na obszarze miasta Chorzowa od końca XVIII wieku do czasów współczesnych)

Drzewiecki W. (2008) Land-use / land cover monitoring based on mulititemporal remote sensing images. Annals of Geomatics, 6, 3: 131-142 (In Polish: Monitoring zmian pokrycia i użytkowania terenu na podstawie wieloczasowych obrazów teledetekcyjnych. Roczniki Geomatyki)

Dulias R. (2010) The influence of mining onlandscape of "Żabie Doły" (Silesian Upland). Kształtowanie środowiska geograficznego i ochrona przyrody na obszarach uprzemysłowionych i zurbanizowanych, 41: 5-12. (In Polish: Wpływ górnictwa na krajobraz "Żabich Dołów" (Wyżyna Śląska).

Dulias R. (2013) Anthropogenic Denudation in Mining Areas on the Example of the Upper Silesian Coal Basin. Wyd. Uniwersytet Śląski, Katowice. (In Polish: Denudacja antropogeniczna na obszarach górniczych na przykładzie Górnosląskiego Zagłębia Węglowego)

Foody G. M. (2002) Status of land cover classification accuracy assessment. Remote Sensing of Environment, 80, 1: 185-201.

Jankowski W. (1961) Niemiecka mapa w skali 1:25 000 na terenach polskich na wschód od Odry i Nysy. Przegląd Geodezyjny, 33, 11. Warszawa: 417-462. 
Kaim D. (2009) Land-cover changes in PolishSlovakian border regions: a case study of the Małe Pieniny Mts. Przegląd Geograficzny, 81, 1: 93-106. (In Polish: Zmiany pokrycia terenu na pograniczu polsko-słowackim na przykładzie Małych Pienin)

Kondracki J. (2002) Regional geography of Poland. PWN- Scientific Publisher, Warsaw: 32-43, 243-256 (In Polish: Geografia regionalna Polski).

Konias A. (2010) A Topographicc Cartography of Prussia and the Prussian Section of Partitioned Poland from the Second Half of XVIII Century to the Half of the XX Century. Wyd. Naukowe Akademii Pomorskiej. Słupsk: 7-9, 33-46, 173-197 (In Polish: Kartografia topograficzna państwa i zaboru pruskiego od II polowy XVIII do połowy XX wieku)

Krüger G., Schnadt J. (2000) Die Entwicklung der geodätischen Grundlagen für die Kartographie und die Kartenwerke 18101945. Berlin-Brandenburg im Kartenbild. Berlin: 26-49.

Kryński S. (1970) Z dziejów triangulacji na ziemiach Polski. Triangulacja pruska 18321914. Studia i materiały z dziejów polskiej nauki, Seria C, 14. Wyd. PWN. Warszawa: 4-82.

Lambin E. F., Turner B. L., Geist H. J., Agbola S. B., Angelsen A., Bruce J. W., Coomes O. T., Dirzo R., Fischer G., Folke C., George P. S., Homewood K., Imbernon J., Leemans R., Li X., Moran E. F., Mortimore M., Ramakrishnan P. S., Richards J. F., Skanes H., Steffen W., Stone G. D., Svedin U., Veldkamp T. A. Vogel C., Xu J. (2001) The causes of landuse and land-cover change: moving beyond the myths. Global Environmental Change, 11, 4: 261-269.

Mazurek K. (2014) Landscape structure changes in the Slepiotka River drainage basin in the period 1824-1993 (The Silesian Upland, Poland). Contemporary
Trends in Geoscience, De Gruyter, 3. Warszawa: 32-40.

Mazurek K. (2015a) Data sources on landscape structure in a highly industrialized area. Environmental \& Socio-economic Studies, De Gruyter, 3, 1. Berlin: 11-19.

Mazurek K. (2015b) Transformation of the structure of the river catchment landscape located in the area of intensive coal exploitation [in:] Landscape Analysis and Planning - Geographical Perspective. Springer-Geography Publishing. Switzerland: 81-90.

Pełka-Gościniak J., Szczypek T. (2008) The main features of the relief of the Upper Silesian Metropolitan Union and its transformations [In:] Dulias R., Hibszer A. (ed.) Upper Silesian Metropolitan Union. Geographical Outline. PTG Branch in Katowice. Sosnowiec: 34-42 (In Polish: Główne rysy rzeźby obszaru Górnośląskiego Związku Metropolitalnego i jego przekształcenia. Górnośląski Związek Metropolitalny. Zarys Geograficzny).

Szaflarski J. 1965. Zarys kartografii. Wyd. II. Wyd. PPWK. Warszawa

Szymura T. H., Dunajski A., Ruczakowska A. M. (2010) Changes in forests surface in the area of Karkonosze National Park between 1747-1977. Opera Corcontia 47/2010 Suppl. 1: 159-166 (In Polish: Zmiany powierzchni lasów na obszarze Karkonoskiego Parku Narodowego w okresie 1747-1977).

Townshend J., Justice C., Li W., Gurney C., McManus J. (1991) Global land cover classification by remote sensing: present capabilities and future possibilities. Remote Sensing of Environment, 35, 2-3: 243-255

Turner M. G., Wear D. N., Flamm R. O. (1996) Land Ownership and Land-Cover Change in the Southern Appalachian Highlands and the Olympic Peninsula. Ecological Applications 6:1150-1172 
Vogelmann J. E., Howard S. M., Yang L. et al., (2001) Completion of the 1990s national land cover data set for the conterminous United States from Landsat thematic mapper data and ancillary data sources. Environmental Monitoring and Assessment, 51, 1:415-428.

Xiubin L. (1996) A Review of the international researches on land use/land cover change. Acta Geographica Sinica, 6.

Yuan F. (2008) Land-cover change and environmental impact analysis in the Greater Mankato area of Minnesota using remote sensing and GIS modeling. International Journal of Remote Sensing, 29, 4: 1169-1184.

\section{Notes}

Messtischblätter 1:25 000, sheet: 3353, Berlin, 1883.

Messtischblätter 1:25 000, sheet: 5779, Berlin, 1942.

Statystyczne Vademecum Samorządowca, 2014. Górnośląski Związek Metropolitalny, Urząd Statystyczny w Katowicach.

The Staatsbibliothek zu Berlin - Preussischer Kulturbesitz http://www.preussischerkulturbesitz.de/ (access 02.12.2014).

Topographic map of Poland 1:10 000, Sheets: M-34-62-B-d-1, M-34-62-B-d-2, M-34-62B-d-3, M-34-62-B-d-4, M-34-63-A-c-1, M-34-63-A-c-3, Surveyor General of Poland, Warsaw, 1994.

Urmesstischblätter 1:25,000, sheet 3353, Berlin, 1827. 